\title{
Developing an effective adaptive monitoring network to support integrated coastal management in a multiuser nature reserve
}

\author{
Pim Vugteveen $^{1}$, Marieke M. van Katwijk ${ }^{1}$, Etiënne Rouwette $^{2}, \underline{H . J . ~ R o b ~ L e n d e r s ~}^{1}{ }^{\text {and Lucien Hanssen }}{ }^{3}$
}

\begin{abstract}
We elaborate the necessary conceptual and strategic elements for developing an effective adaptive monitoring network to support Integrated Coastal Management (ICM) in a multiuser nature reserve in the Dutch Wadden Sea Region. We discuss quality criteria and enabling actions essential to accomplish and sustain monitoring excellence to support ICM. The Wadden Sea Long-Term Ecosystem Research project (WaLTER) was initiated to develop an adaptive monitoring network and online data portal to better understand and support ICM in the Dutch Wadden Sea Region. Our comprehensive approach integrates ecological and socioeconomic data and links research-driven and policy-driven monitoring for system analysis using indicators of pressures, state, benefits, and responses. The approach and concepts we elaborated are transferable to other coastal regions to accomplish ICM in complex socialecological systems in which scientists, multisectoral stakeholders, resource managers, and governmental representatives seek to balance long-term ecological, economic, and social objectives within natural limits.
\end{abstract}

Key Words: adaptive monitoring; capacity building; DPSIR; integrated coastal management; monitoring excellence; Wadden Sea

\section{INTRODUCTION}

Integrated coastal management (ICM) has been promoted worldwide for attaining more sustainable management of coastal zones by means of a dynamic, multidisciplinary, and iterative process. Integrated coastal management seeks to balance longterm ecological, economic, and social objectives within the limits set by natural dynamics (Bowen and Riley 2003, Olsen and Nickerson 2003).

Worldwide, applications of ICM vary across the diverse geographical, political, socioeconomic, and ecological settings in which they are applied. Despite the place-based nature of ICM activities, there are a number of basic traits in successful ICM implementation (reviewed in Stojanovic et al. 2004, Taljaard et al. 2013). There is wide recognition among scientists and resource managers that successful marine management approaches, including ICM, involve stakeholder participation, adaptive monitoring, and evaluation as basic components for effective strategies (Armitage et al. 2009, Lindenmayer and Likens 2009, Douvere and Ehler 2011).

Research and monitoring are key components for informed policy and decision making (Day 2008, Kabat et al. 2012), especially when coastal management aims to achieve a sustainable balance between protecting nature and allowing multiple human uses. However, an important challenge is to evaluate, integrate, and extend existing monitoring systems to provide a more effective and less biased platform for decision making toward sustainability (Kates et al. 2001, Lindenmayer and Likens 2009).

When setting up monitoring, it is necessary to be aware of several major issues known to hinder monitoring effectiveness and efficiency. These include: selecting the wrong drivers for setting up monitoring, i.e., short term political demands rather than building a sound knowledge base; high ambition levels and resource constraints; and importantly, a poor initial design and a lack of clarity regarding goals and components (Hockings et al. 2008, Chapman 2012, Lindenmayer et al. 2012).
We elaborate the necessary conceptual and strategic elements for developing an effective adaptive monitoring network to support ICM in a multiuser nature reserve. We outline these elements for the Dutch Wadden Sea Region, within the context of the Wadden Sea Long-Term Ecosystem Research project (WaLTER). The Wadden Sea system is recognized as one of the world's most valuable coastal areas, having received a World Heritage status for the Dutch and German parts in 2009 (CWSS 2008, Kabat et al. 2012). The WaLTER project (2011-2015) was initiated to develop a plan for adaptive monitoring to better understand and integrate management of environmental issues relevant to the Dutch Wadden Sea. WaLTER aims to integrate and improve existing monitoring programs, fill possible gaps in the current monitoring network, and make existing and new data more readily accessible (WaLTER project team 2010). The main product of the project is an online portal that makes monitoring data and information available and accessible for all stakeholders.

We describe a conceptual framework for adaptive ICM of the Wadden Sea Region that includes monitoring. We then propose a strategic outline for establishing an adaptive monitoring network, which includes an indicator framework. We elaborate quality criteria necessary for realizing the proposed monitoring network and data and information portal. We address credibility, legitimacy, and salience as fundamental criteria in data and information production, as well as quality criteria for assuring monitoring excellence of the WaLTER portal. We further discuss enabling actions essential for realizing and sustaining adaptive long-term monitoring in support of ICM.

\section{CONCEPTUAL FRAMEWORK FOR INTEGRATED COASTAL MANAGEMENT (ICM)}

Integrated coastal management refers to the integrated management of all policy processes affecting the coastal zone, addressing land-sea interactions of coastal activities in a coordinated way with a view to ensuring the sustainable development of coastal and marine areas (European Commission

${ }^{1}$ Department of Environmental Science, Institute for Water and Wetland Research, Radboud University, ${ }^{2}$ Methodology Department, Institute for Management Research, Radboud University, ${ }^{3}$ Deining Societal Communication and Governance, Nijmegen 
2002). Integrated coastal management aims to ensure that management or planning decisions are addressed coherently across ecological as well as socioeconomic domains guaranteeing the sustainable use of coastal and marine resources. Key features of effective ICM are comprehensiveness, i.e., taking a sufficiently wide scope and full view of issues, and cooperation among stakeholders (Stojanovic et al. 2004, Belfiore et al. 2006, Taljaard et al. 2011, Vugteveen 2013). Table 1 summarizes the basic premises of ICM as commonly proposed in existing literature.

Table 1. Common premises of an adaptive integrated coastal management (ICM) approach (based on Belfiore et al. 2006, Taljaard et al. 2011).

\section{Premises}

a) Management is ecosystem based, and the system is perceived as a social-ecological system (SES) with the aim to balance ecological, economic, and social objectives toward sustainable development;

b) Management is comprehensive, a sufficiently wide scope and full view of issues is taken;

c) Management is adaptive: monitoring and evaluation are key phases in the management process, which is directed at testing assumptions, adaptation, and institutional learning;

d) Management is region based and takes a long-term perspective;

e) Management is participatory and directed at comanagement by means of facilitated interactions among policymakers, scientists, and stakeholders;

f) Management is evidence based and is supported by insights from scientific research.

Within natural resource management, the adaptive approach has become the strategy of choice for optimal decision making in the face of uncertainty through iterative steps of learning by doing. The conceptual underpinnings for adaptive management are simple: there will always be inherent uncertainty and unpredictability in the dynamics and behavior of social-ecological systems (SESs) because of system complexity involving nonlinear relations (Liu et al. 2007), yet management decisions must still be made (Allen and Gunderson 2011). In its original conception, adaptive management emphasizes the design of diagnostic management experiments to reduce uncertainty. In this approach, learning is explicitly incorporated in management objectives, meaning that decisions that improve learning are valued over those that do not. Later elaborations of the concept incorporated ideas of decision theory with less emphasis on experimentation as a management objective in itself, treating learning in a practical sense insofar as it improves decision outcomes (McFadden et al. 2011). We adhere to the latter perspective. All adaptive management approaches, however, share system monitoring and evaluation steps to structure and reduce uncertainty over time, and they aim to optimize management strategies by incorporating learning results from these processes (Belfiore et al. 2006).
Adaptive ICM includes a cyclic management process consisting of deliberation, planning, implementation, assessment, learning, and adjustment steps, as depicted in Figure 1 (blue-colored steps). The circular form emphasizes the importance of iterative evaluation steps serving continuous management adjustments based on new learning, thus allowing for a systematic refinement of the overall implementation process (CMP 2007, Douvere and Ehler 2011, Taljaard et al. 2013). Generation and use of data and information through monitoring, and subsequent learning and capacity building are key steps to this adaptive process. These steps can be conceptualized as separate process cycles serving the overall ICM process, i.e., comprising an information cycle and a capacity building cycle, respectively.

Fig. 1. The overall integrated coastal management (ICM) process cycle (center, in blue) is based on an adaptive management approach and involves an information cycle (right, in green) based on adaptive monitoring (right), and a capacity building cycle (left, in red) serving scientific and societal capacity building (left; modified after CMP 2007, Williams and Brown 2013).

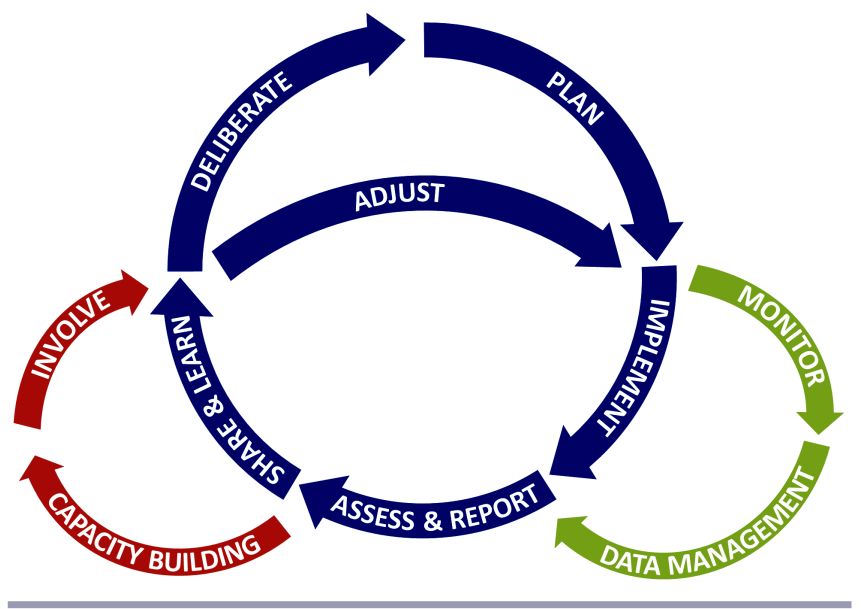

Monitoring presents the main component in the information cycle (right part of Fig. 1 in green), which underlies operational management. Information derived from monitoring may be used by managers to improve the performance of their strategies by evaluating the effectiveness of management actions and contributing to transparency and accountability for improving future planning (Pomeroy et al. 2005, Pullin and Stewart 2006, Hockings et al. 2008). The information cycle includes the identification of information needs, implementing of monitoring, i.e., data collection and proper data management, and subsequent assessment and reporting to inform decision makers, managers, and stakeholders involved in ICM (Timmerman et al. 2000).

Again, the suggested cyclicity of the information steps shown in Figure 1 signifies the continuous process of connecting and adapting the design and operation of the monitoring system to the information expectations and/or products required by these ICM actors. Lindenmayer and Likens (2009) explicitly defined adaptive monitoring as a process in which the development of conceptual models, question setting, experimental design, data 
collection, data analysis, and data interpretation are linked as iterative steps in a cyclic process. An adaptive monitoring program, then, evolves in response to new questions, new information, situations, or conditions, however without distorting or breaching the continuity and/or integrity of the data record.

Though grounded in monitoring-based facts, decisions on management strategies and actions require careful evaluation, deliberation, and negotiation. The adaptive ICM process relies on the capacity of involved managers and actors to learn and implement their learning in management activities. The capacity building cycle (left part of Fig. 1 in red) depends on learning-bydoing at two levels: institutional/social and technical learning (Williams and Brown 2014).

Institutional or social learning involves the sharing and reflection on facts and values, which takes place among individuals and groups, and serves to improve deliberation and planning in the ICM process and the taking of agreed actions. It requires periodic evaluation and reconsideration on how management performs and should be otherwise set up or continued (Reed et al. 2010, Biggs et al. 2012). As part of institutional learning the "adjust" process arrow in the central part of Figure 1 depicts the outcome of technical learning aspects (Williams and Brown 2014). This iterative sequence of decision making, monitoring, and assessment is focused at technical management abilities, including innovations, to aid in reaching desired management goals via the reduction of knowledge uncertainties.

Figure 1 expresses that learning, institutional as well as technical, is a driving process for capacity building, serving ICM by enhancing the capabilities of involved actors to influence and participate in management planning and implementation. Institutional learning processes may be enhanced by establishing dialogue among the actors involved in ICM to facilitate taking agreed action (Parr et al. 2003, Hanssen et al. 2009). Concepts like adaptive comanagement and adaptive governance emphasize stakeholder processes for more inclusive and democratic management, focusing on participation in decision making (Armitage et al. 2009, Cundill and Fabricius 2009, Rist et al. 2013). Participation may also extend to monitoring and management activities wherein citizen volunteers assist in data collection or conduct research themselves, i.e., citizen science serving so called community-based monitoring (Conrad and Hilchey 2011). Essential to capacity building is that the network of involved actors evolves and strengthens over time through dynamic interactions between coastal community members, either being temporally involved actors or constituting more formal partnerships within and between government, business, civil society, and the scientific and professional communities (Taljaard et al. 2013).

\section{THE WaLTER STRATEGIC OUTLINE FOR MONITORING}

We further elaborate the presented concept of ICM and apply it to adaptive monitoring in the Dutch Wadden Sea Region. Figure 2 summarizes a strategic outline, which aims for a comprehensive and flexible monitoring framework. It combines different roles of monitoring and distinguishes between two main services; i.e., generating data/information and enabling their use. This translates to supplying monitoring data as well as offering derived information products that are useful to ICM, i.e., able to inform management and facilitate stakeholder involvement. These outputs are explicitly anticipated for the WaLTER network and its online portal (Vugteveen et al. 2014a). Monitoring data refers to (meta)data of the actual measurements, whereas monitoring information is structured as a set of relevant indicators derived from the monitoring data, involving processing and calculation steps on these data.

Monitoring efforts serve different purposes in ICM that are basically research-driven or policy-driven. Research-driven monitoring is directed at data collection for assessing those indicators that explain cause-effect relationships in humanenvironmental interactions, preferably those that are responsive to management actions. More than policy-driven monitoring, it is aimed at building deeper system understanding in support of evidence-based policies and management measures. Policy-driven monitoring, then, is aimed at signalling trends in the system and at evaluating implemented policies and management measures, which subsequently may be adjusted if deemed necessary. Note that research-driven and policy-driven monitoring do not represent exclusive monitoring activities and do not suggest a traditional distinction in research and policy.

\section{Use of indicators}

A long-standing problem with the design and implementation of monitoring programs has been the question of what to assess through monitoring. Expressed assessment endpoints, captured as indicators, may either serve as description of system stressors and processes, assessment of management performance, or evaluation of management effectiveness (Parr et al. 2003). Because of its wide use in environmental management the term "indicator" has become a profoundly ambiguous term, which has been given different meanings in different contexts (Turnhout et al. 2007). We define an indicator as a component or a measure of environmentally relevant phenomena used to describe socialecological conditions, evaluate system changes, or prescribe management goals (Heink and Kowarik 2010). It generally comprises a statistic or parameter, which should have significance beyond the properties of the statistic itself, in support of deciding on potential management actions (Bowen and Riley 2003, Gudmundsson 2003).

In capturing important SES phenomena for management, the indicator set should at least aim to reflect all the elements of major causal-effect relations and social responses in the social-ecological system, allowing identification of the driving forces of change and their consequential impacts. This logic is reflected in the driving forces-pressures-state-impacts-responses (DPSIR) framework, which is commonly used for evaluating the social-ecological effects of human activities (Bowen and Riley 2003, Maxim et al. 2009, Atkins et al. 2011).

According to Rapport and Hildén (2013) however, many applications of the DPSIR logic tend to be primarily focused on describing system state and documenting the general pressures that are believed to impact system condition. In practice, less attention is given to documenting the status and trends of the human driving forces, let alone to the effectiveness of policy responses. This emphasizes the need for a greater convergence in conventional "state" monitoring and the monitoring of (human) actions underlying changes in system state when developing indicators. 
Fig. 2. Strategic outline for the Wadden Sea long-term ecosystem research project (WaLTER) monitoring network. The lower part of the figure expresses that monitoring activities generate data and information for different research-driven and policy-driven purposes. The upper part expresses that information and data outputs serve specific goals of integrated coastal management (ICM) actors. *SES - social ecological system

ICM component: Punction: Purpose:
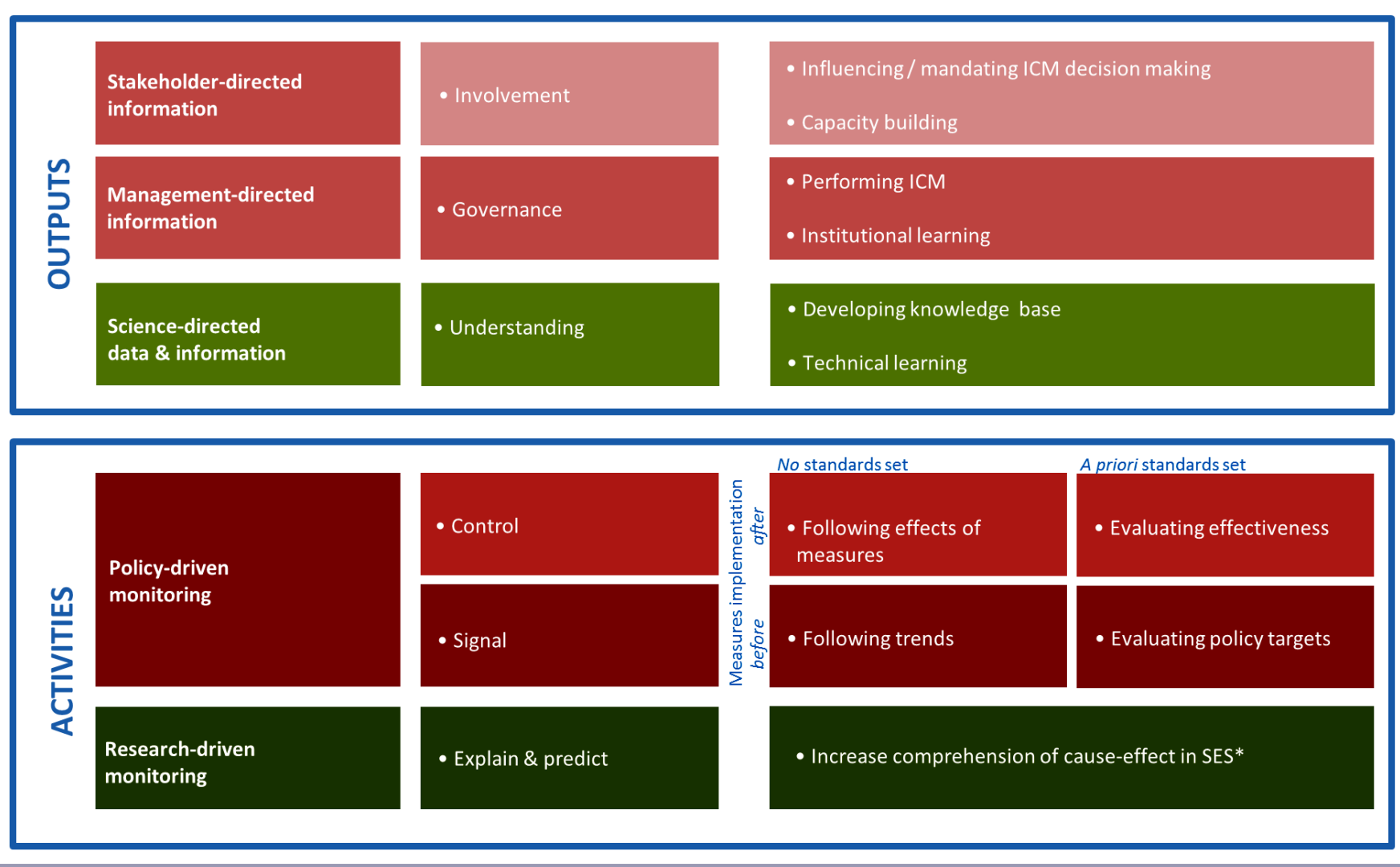

Sparks et al. (2011) proposed a simplified version of the DPSIR framework, structuring indicators into four focal areas: threats to the system, i.e., pressures, the state of the system, ecosystem services and resulting benefits, and policy responses. Based on practical experiences, this framework is considered to be more logical, understandable, user-friendly, policy relevant, and communicable (Sparks et al. 2011, Jones et al. 2013). Hence we distinguish four relevant types of indicators: (1) response indicators measuring the implementation of policies or management measures; (2) pressure indicators monitoring the extent and intensity of the causes of (unwanted) SES changes; (3) state indicators analyzing the condition and status of aspects of the SES; and (4) benefits indicators quantifying the benefits that humans derive from the SES.

The proposed framework has practical advantages for managers trying to understand the causal linkages between action and outputs. The order of indicators presented above therefore intentionally begins with responses, rather than pressures, to emphasize that the guidance of policy and other practical actions is the central purpose of the indicator set (Sparks et al. 2011). Differing from the traditional DPSIR categorization, driving forces for change are not a separate category, but taken into account within both the response and the pressure categories.
Also the impacts category, focused on negative effects of humans on the environment, is interpreted in terms of positive humanenvironmental relations, i.e., the benefits humans can derive from a healthy environment. Following the same reasoning, Kelble et al. (2013) replaced the impact category by ecosystem services in their DPSER framework. The proposed framework of indicators as such aims to capture a greater diversity of discourses existing in social-ecological systems and to provide more comprehensive information to decision makers than the traditional DPSIR model (Chapman 2012). Figure 3 is complementary to Figure 2 and summarizes the use of response, pressure, state, and benefits indicators for different monitoring purposes.

Social-ecological systems (SES) themes and monitoring needs Arriving at a comprehensive indicator set for management requires the systematic identification of essential system components, their mutual (often hierarchical or reciprocal) relationships, and their contributions to the performance of other components and the total system (Bossel 2001). Obviously most management issues cannot be characterized by linear causal chains acting in one single system. In reality, many issues involve cumulative causation (Maxim et al. 2009). In addition, there are cases in which it can be argued that individual indicators could belong to more than one category; for instance one could consider 
the proportion of fish stocks that are overexploited as an indicator of pressure, but it could also be considered an indicator of the state of the system. Understanding and explicitly stating the logical connections among all four indicator types (Fig. 3) is important if selected indicators are to support management effectively, because this makes clear the assumptions and working hypotheses about the mechanisms by which policies and actions affect the system (Sparks et al. 2011).

Fig. 3. The use of response, pressure, state, and benefits indicators for different monitoring foci; effectiveness, performance, or processes. The indicator categories and their interrelations represent a simplified driving forces-pressuresstate-impacts-responses (DPSIR) logic, based on Sparks et al. 2011. *SES - social-ecological system

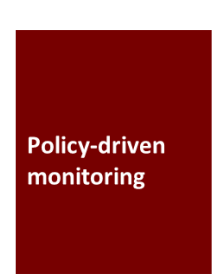

Focus of the monitoring:

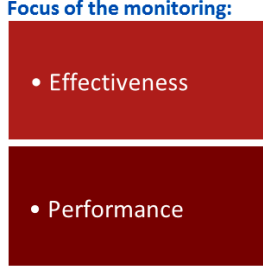

DPSIR logic for targeting SES* variables:
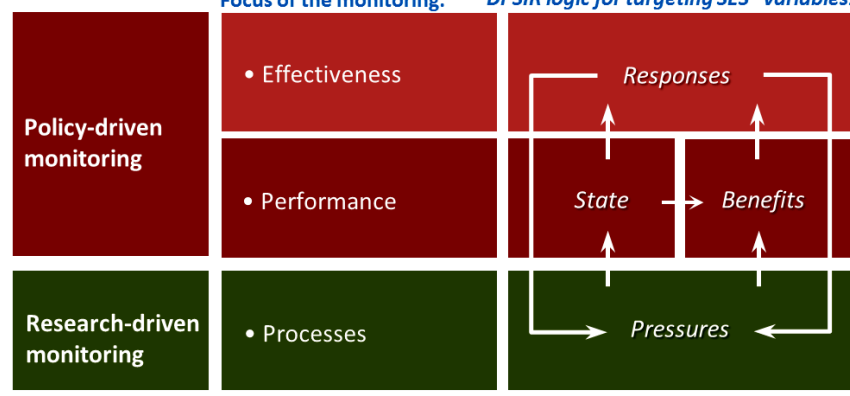

Lindenmayer and Likens (2009) outlined several principles for adaptive monitoring, which serve to identify effective indicators and determine appropriate monitoring design, thereby enhancing effectiveness of monitoring activities. These principles express the need to: (1) carefully assess information needs and craft tractable questions at the outset of a monitoring program; (2) use wellconceived models to conceptualize current understandings of the system and to make predictions about behavior and response; (3) include a rigorous statistical design. Most important is that measurement variables for monitoring in the field are fully congruent with articulated assessment variables and are as such able to address the objectives and questions established from the outset (Lindenmayer et al. 2012). Adhering to solid design principles will not only avoid unnecessary data collection and miscommunication with stakeholders, i.e., what needs to be monitored, but will also promote the assessment of the long-term effectiveness of any management actions (Chapman 2012).

The WaLTER project setup involves separate work packages to implement each of the above three principles (WaLTER project team 2010). Online surveys helped us to make a comprehensive assessment of information needs and monitoring network requirements among stakeholders and monitoring experts in the Dutch Wadden Sea Region (Vugteveen et al. 2014a). Extensive input on portal contents and design was generated through stakeholder consultation by performing assessments of information needs found most important by user groups. In addition, a system dynamics modeling approach called group model building (GMB) was used as a diagnostic participative tool for understanding the determinants of two characteristic SES issues, i.e., fisheries (Vugteveen et al. 2014b) and tourism
(Vugteveen et al. 2014c), and exploring salient SES indicators for management. Table 2 illustrates relevant SES themes, monitoring needs, and indicator types for the Wadden Region as extracted from these monitoring assessments and GMB sessions.

\section{MONITORING EXCELLENCE}

In times of diminishing rather than increasing budgets for monitoring, the evaluation of the effectiveness and efficiency of monitoring activities, i.e., monitoring excellence, has become increasingly important (Pomeroy et al. 2005, Pullin and Stewart 2006, Jacobson et al. 2014). Monitoring programs are often too ambitious and unachievable because of resource constraints, and they are known to fail when monitoring excellence is not actively maintained (Lindenmayer et al. 2012). Monitoring excellence, in this case, refers to the systematic use of quality criteria and tools in management, which are aimed at improving monitoring performance. These criteria should be part of the operational design of any monitoring network (Black and Groombridge 2010, Sherman 2014). Adaptive monitoring activities and expected results need to be aligned with procedural, organizational, and financial measures of success. We present quality criteria for evaluating the appropriateness of monitoring, organizational feasibility, and operational performance. They apply to the challenges encountered in management and monitoring in a broad sense and are not exclusive to adaptive aspects, i.e., learning and reducing uncertainty (Rist et al. 2013).

\section{Excellence in information, organization, and operationalization} Monitoring and evaluation are performed in ICM to assess the extent to which what we are doing is sensible, equitable, and effective (Day 2008, Douvere and Ehler 2011). For these respective aims, monitoring and evaluation efforts are required to be credible (C), legitimate (L), and salient (S). Credibility refers to the authority and reliability of the information. In the context of adaptive management, this also relates to how well monitoring efforts are able to reduce uncertainties for decision making. Next, legitimacy refers to how fair and respectful the production of information is in terms of considering opposing values, concerns, and perspectives of different stakeholders. Finally, salience deals with how relevant and usable information is to decision-making bodies or stakeholders. These aspects are all highly significant in the Wadden Sea Region where conflicts of interest frequently arise (Hanssen et al. 2009, Runhaar and van Nieuwaal 2010). Although credibility, legitimacy, and salience are considered critical in relation to evaluating ICM effectiveness, they are often neglected (Cash et al. 2003). They are therefore explicitly considered as quality criteria in the WaLTER design and its strategic planning. Figure 4 visualizes the relation between the three information attributes, for easy reference here coined "the CLS attribute triangle," and the flow of generated data and information enabling capacity building through information use and learning. The CLS attribute triangle expresses that credibility, legitimacy, and salience interact, and that each is significant for a specific phase of the ICM process.

In the WaLTER project, credibility challenges monitoring design to be based on robust and state-of-the-art science-based models about the ecological and socioeconomic functioning of the system. The WaLTER project develops an online portal for data as well as offering information products and services. Legitimacy trade-offs apply to the translation of data to information, 
Table 2. The Wadden Sea Long-Term Ecosystem Research project (WaLTER) monitoring themes and topics in the Dutch Wadden Sea Region.

\begin{tabular}{|c|c|c|c|c|}
\hline $\begin{array}{l}\text { Themes and } \\
\text { topics }\end{array}$ & $\begin{array}{l}\text { Examples of monitoring } \\
\text { needs }\end{array}$ & $\begin{array}{l}\text { Main types of } \\
\text { relevant indicators }\end{array}$ & Type of monitoring & $\begin{array}{l}\text { Principal focus of } \\
\text { monitoring }\end{array}$ \\
\hline \multicolumn{5}{|l|}{ Abiotics } \\
\hline Climate & Effects of changing storm regimes & Pressure, state & Research driven & Process \\
\hline $\begin{array}{l}\text { Morphology } \\
\text { Biotics }\end{array}$ & Sedimentation & Pressure, state & Research driven & Process \\
\hline Biodiversity & Distribution of invasive species & Pressure, state & $\begin{array}{l}\text { Research and policy } \\
\text { driven }\end{array}$ & Process \\
\hline Habitat & $\begin{array}{l}\text { Effect of closed areas on biodiversity } \\
\text { (Natura } 2000 \text { legislation) }\end{array}$ & State, response & Policy driven & Effectiveness \\
\hline Food web & Primary production & Pressure, state & $\begin{array}{l}\text { Research and policy } \\
\text { driven }\end{array}$ & Process \\
\hline \multicolumn{5}{|l|}{ Human use } \\
\hline Coastal protection & $\begin{array}{l}\text { Effects of ecosystem engineering } \\
\text { ("building with nature") }\end{array}$ & Benefits, response & Policy driven & Effectiveness \\
\hline Fisheries & Development of mussel seed beds ${ }^{\dagger}$ & Benefits, pressure & Policy driven & Performance \\
\hline Agriculture & $\begin{array}{l}\text { Market development of regional products } \\
\text { with Wadden label }\end{array}$ & Benefits, pressure & Policy driven & Performance \\
\hline $\begin{array}{l}\text { Recreation and } \\
\text { tourism }\end{array}$ & Development of tourist facilities ${ }^{\dagger}$ & State, benefits & Policy driven & Performance \\
\hline Energy and mining & Extraction of natural gas & Benefits, pressure & Policy driven & Performance \\
\hline Ports and transport & Development of port infrastructures & Benefits, pressure & Policy driven & Performance \\
\hline
\end{tabular}

${ }^{\dagger}$ Monitoring needs and relevant indicators have been further explored in two group model building sessions focused on fisheries (Vugteveen et al. 2014b) and tourism (Vugteveen et al. 2014c).

Fig. 4. The conceptual relations of information attributes, i.e., the C (credible) L (legitimate) S (salient) attribute triangle, with the information cycle and the capacity building cycle serving the overall integrated coastal management (ICM) process.

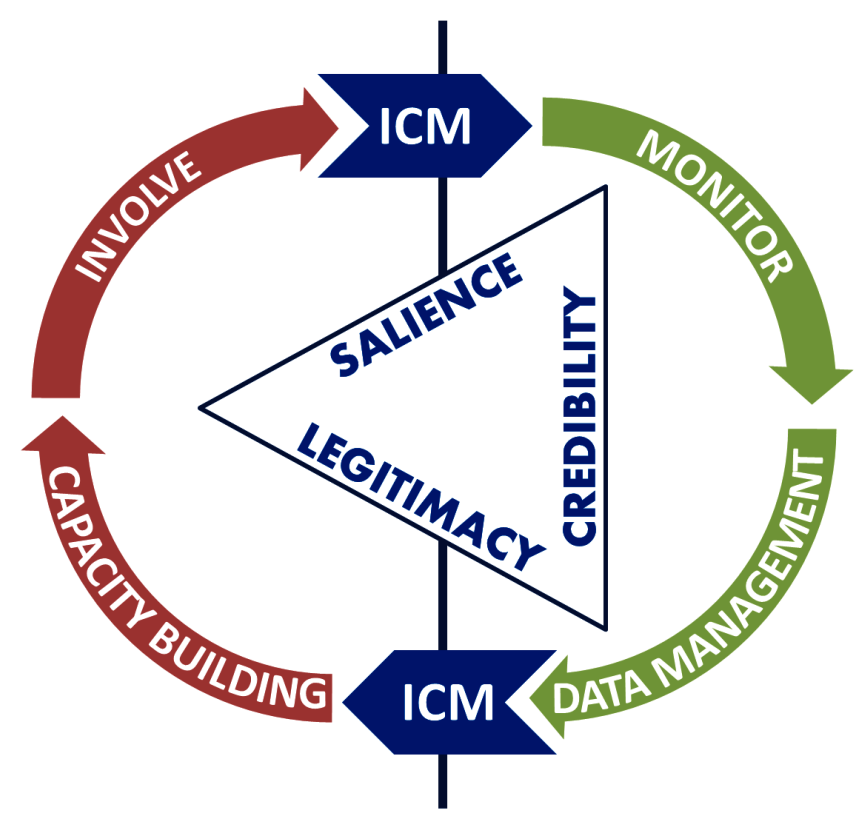

especially information that is produced to be used in policy making. Finally, the salience criterion expresses that relevant information needs of potential users should be taken fully into account in monitoring strategies and design of the WaLTER portal. Especially because the salience of information production is a generally under appreciated aspect of monitoring design (Lindenmayer and Likens 2009). Specific methodologies for assessing information needs and monitoring network requirements may be applied to appropriately address salience such as described in detail in Vugteveen et al. (2014a) for the WaLTER case.

Quality criteria for information excellence are technically part of a wider set of essential procedural, organizational, and operational measures that need to be considered for establishing effective and efficient monitoring (Stojanovic et al. 2004, Black and Groombridge 2010, Khosravi and Chavan 2012). In companies, the use of business excellence models is common to help evaluate organizations on their way toward excellence, helping them understand the gaps, and then providing solutions. Internationally, the business excellence model of the European Foundation for Quality Management (EFQM) is probably the most widely used framework. The EFQM model is founded on a set of beliefs and behaviors of organizations that over time managed to have consistently good financial results, effective operations, and satisfied customers (ECBE 1999). More recently it has also been applied in conservation management settings as well as in scientific organizations (Black and Groombridge 2010). We adopt the framework to provide insight into the critical factors, processes, and results for effective monitoring network design. Following the EFQM model, Figure 5 summarizes nine excellence domains, which help to align the design and functioning of monitoring networks. These excellence domains pertain to people, processes, and performance, the first two categories enabling the latter. 
Fig. 5. Excellence domains for achieving efficient and effective monitoring processes and outcomes (modified after Black and Groombridge 2010).

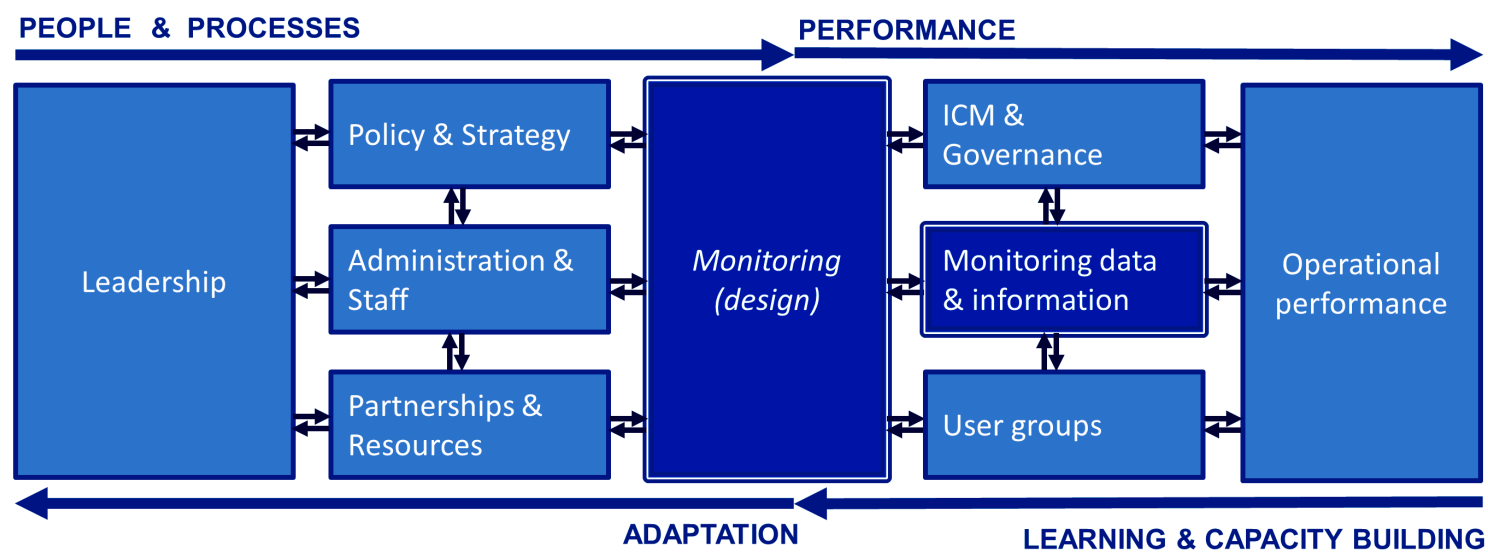

\section{Monitoring excellence in the Dutch Wadden Sea Region}

The excellence domains presented in Figure 5 are further exemplified in the case of developing the WaLTER portal and monitoring network. The figure communicates that good leadership and staffing, a clear strategy, well-developed partnerships, and secured resources are essential for realizing an appropriate and feasible monitoring network structure.

The current organizational structure of the WaLTER project consists of a joint venture of research institutes and monitoring organizations that carry out long-term measurements in the Wadden Sea Region (WaLTER project team 2010). Cooperation is established with main institutions coordinating regional research and funding, i.e., the Dutch Waddenacademie, a public agency programming and promoting research, and the Dutch Waddenfonds, a public fund for projects driving sustainable developments in ecology and economy in the Wadden Sea area. The people aspects, in terms of leadership, staff, and partnerships, are pivotal to the success of the monitoring network (Folke et al. 2005, Lindenmayer and Likens 2010). The main product of the WaLTER project, i.e., the online portal, will function as a data and information retrieval system of which the data content depends on successful cooperation with organizations maintaining monitoring databases, i.e., the data owners.

In the WaLTER project, community engagement has been a priority from the start. Extensive input on portal contents and design has been generated through stakeholder consultation by performing information needs assessments among user groups (Vugteveen et al. 2014a). Within the WaLTER organization, an advisory committee and a data owner board have been installed that include key representatives from governmental and funding agencies, monitoring organizations, and data owning organizations. These structures and processes are all essential to ensure legitimacy and salience of the monitoring network. The advisory committee supervises activities of the WaLTER project and provides feedback and advice on societal and scientific relevance as well as on institutional support. The data owner board includes representatives of different data owners, i.e., organizations that hold managerial and financial accountability for a dataset and that have legal ownership rights. The main task of this board is to advise on accessibility of existing and new data and on how to harmonize current monitoring activities within the overall WaLTER monitoring strategy.

The excellence domains shown on the right-hand side of Figure 5 relate to the target results of the WaLTER portal. Performance results relate to the actual content of the WaLTER portal and its use, as well as tangible deliverables for ICM in the Wadden Sea Region (Fig. 1). These deliverables include offering evidencebased information products and appropriate indicators to be used for balanced decision making (Daams and Sijtsma 2013). A sounding board has been installed, in which main user groups are represented, to provide direct feedback on portal design, content, and functionality. For each excellence domain presented in Figure 5 key enabling actions are listed in Table 3 , which are essential to successfully realizing the WaLTER monitoring network and portal.

\section{DISCUSSION AND CONCLUSIONS}

Our study elaborated the necessary conceptual and strategic elements for developing an effective adaptive monitoring network to support integrated coastal management (ICM). We outlined these elements within the context of the WaLTER project, which aims at realizing an adaptive monitoring network for the Dutch Wadden Sea Region. Progressively building a deeper understanding about nature, cultural heritage, and social economy is necessary for balancing its multiple uses (Kabat et al. 2012, Daams and Sijtsma 2013), especially given the World Heritage status of the region.

Beyond establishing a mere monitoring network for collecting data, WaLTER aims to be an active "learning institution" for capacitating stakeholders, implementing adaptive monitoring processes in response to new information questions by stakeholders, or new scientific insights. Citizen science initiatives (Conrad and Hilchey 2011) are part of the WaLTER approach. A recent instrument called Hotspotmonitor is worth mentioning in this respect. Sijtsma et al. (2012) developed a web-based tool for the (inter)national Wadden Sea Region that offers a spatially explicit way to measure attractiveness of the landscape, places, and specific individual experiences. A viewer has been applied in 
Table 3. Enabling actions for realization of the Wadden Sea Long-Term Ecosystem Research project (WaLTER) monitoring network and portal.

\begin{tabular}{|c|c|c|}
\hline Excellence domains & Enabling actions & WaLTER project implementation \\
\hline 1. Leadership & $\begin{array}{l}\text { Communicating clear vision and goals } \\
\text { Sustained commitment }\end{array}$ & $\begin{array}{l}\text { Advisory committee installed; cooperation with the } \\
\text { Waddenacademie (integrated research agenda); cooperation } \\
\text { with Waddenfonds }\end{array}$ \\
\hline 2. Policy and strategy & $\begin{array}{l}\text { Implementing vision in monitoring setup } \\
\text { Formulating data sharing policy }\end{array}$ & $\begin{array}{l}\text { (Meta) data protocols established; monitoring plan to be } \\
\text { attuned in cooperation with monitoring organizations }\end{array}$ \\
\hline $\begin{array}{l}\text { 3. Administration } \\
\text { and staff }\end{array}$ & $\begin{array}{l}\text { Implementing organizational structure } \\
\text { Appointing skilled staff }\end{array}$ & $\begin{array}{l}\text { Managerial structure and technical infrastructure } \\
\text { accommodated to WaLTER portal and data protocols }\end{array}$ \\
\hline 4. Partnerships and resources & $\begin{array}{l}\text { Involving committed partners } \\
\text { Ensuring continuity in budget }\end{array}$ & $\begin{array}{l}\text { Data owner board installed; cooperation with regional } \\
\text { ecological and economic programs; new funding pending }\end{array}$ \\
\hline 5. Monitoring & $\begin{array}{l}\text { Ensuring scientific robustness in protocols } \\
\text { Achieving compatibility in regional monitoring } \\
\text { efforts and between programs }\end{array}$ & $\begin{array}{l}\text { Separate work packages in place for employing conceptual } \\
\text { models, methodological, and statistical techniques; } \\
\text { cooperation with main monitoring agencies }\end{array}$ \\
\hline $\begin{array}{l}\text { 6. Monitoring data and } \\
\text { information }\end{array}$ & $\begin{array}{l}\text { Enabling access to all major databases } \\
\text { Establishing easy to use interface }\end{array}$ & $\begin{array}{l}\text { Monitoring organizations and databases are committed; } \\
\text { multilevel functionality of portal (from infographics toward } \\
\text { GIS applications) }\end{array}$ \\
\hline 7. ICM and governance & $\begin{array}{l}\text { Linking monitoring to policy making } \\
\text { Facilitating comanagement }\end{array}$ & $\begin{array}{l}\text { Advice to provinces on the role of monitoring in } \\
\text { management; joint learning of all stakeholders in science- } \\
\text { policy-interface facilitated }\end{array}$ \\
\hline 8. User groups & $\begin{array}{l}\text { Meeting expectations of users } \\
\text { Being open to new demands and insights }\end{array}$ & $\begin{array}{l}\text { Information needs of user groups assessed; sounding board } \\
\text { with user group representatives installed for feedback on } \\
\text { portal functionality }\end{array}$ \\
\hline 9. Operational performance & $\begin{array}{l}\text { Producing tangible deliverables for ICM } \\
\text { Respecting budget and time frame }\end{array}$ & $\begin{array}{l}\text { Offering evidence-based information and appropriate } \\
\text { indicators; administration is accountable and transparent }\end{array}$ \\
\hline
\end{tabular}

the WaLTER website. In September 2014, the beta version of the website and data portal went online to be followed by a scheduled definitive release in May 2015 (see http://www.walterwaddenmonitor. org).

Next to a conceptual framework, we identified monitoring excellence criteria as essential in setting up and implementing effective monitoring activities: credibility, legitimacy, and salience (Fig. 4). Consideration of these criteria ensures that scientifically robust and effective information is provided. Designers and operators of monitoring networks can specifically learn from business models in "running" and evaluating a monitoring network (Fig. 5; Black and Groombridge 2010, Khosravi and Chavan 2012).

Although monitoring excellence criteria are an integral part of the WaLTER project setup, it is also necessary to be aware of some particular bottlenecks associated with a long-term monitoring network. These are: (1) continuity in sufficient budget, (2) vulnerability to institutional changes, and (3) retainment of professional capacity (Lindenmayer et al. 2012).

Access to sufficient funding is an obvious factor influencing the success of WaLTER. For monitoring programs there is often a fundamental mismatch between long-term monitoring aspirations and short-term realities of funding and political cycles. The current project and realization of the portal is financed by the Waddenfonds and by the provinces of Noord-Holland and Friesland. Technical development of the portal itself has been financially secured but further deployment and implementation of the WaLTER monitoring network structure will require additional public and private funding. It is therefore essential for the WaLTER project, and adaptive SES monitoring networks in general, to build trust and prove its usefulness to funding agencies and regional industries, e.g., fisheries, agriculture, shipping, tourism, and energy production. The importance of WaLTER has been acknowledged by the Waddenfonds and in policy documents conveying that long-term adaptive monitoring is not a luxury but should be a public service and a core part of responsible ICM (Algemene Rekenkamer 2013, Waddenfonds 2014).

A second potential bottleneck for maintaining monitoring in the long-term is the vulnerability to institutional changes. To strengthen monitoring and learning capabilities for the long-term, the WaLTER project aims at formal embedding within the regional governance structure. Establishing ownership of the portal and the monitoring network thereby is an essential aspect. In the case of WaLTER, it is a logical next step to become formally associated with the Dutch Waddenacademie (RCW 2014). This academic institute fulfils a formal knowledge brokering role in governance of the Wadden Sea Region by identifying gaps in knowledge about nature, cultural heritage, and social economy, by programming research and monitoring, and by disseminating the outcomes (Waddenfonds 2014). Within the Waddenacademie, WaLTER can function as a reference platform of reliable quantitative data and information against which future management and scientific progress can be compared. The platform can develop into an institution for knowledge management. As opposed to being a platform for mere data and information handling, this institution can be directed at creating information combined with tacit experience, context, and critical reflection. Monitoring programs require the integration of both good science and good management practices. Close collaboration between those with a clear idea of what is needed, i.e., policy makers and stakeholders, and those who can provide the technical and practical skills, i.e., scientists and nature 
managers, is essential. At an institutional level this monitoring platform may evolve to coordinate the activities of monitoring organizations, including private companies, and broker new partnerships and collaborations among stakeholders and monitoring organizations.

Next to vulnerability to institutional change, a third bottleneck is establishing and retaining professional capacity within the organization. Important in this respect is to encourage the training of monitoring professionals, promote citizen science, and improve the skill sets essential for good monitoring, including experimental design, statistical analysis, and database management. Development of professional capacity also includes the promotion of technical innovations in continuously improving monitoring activities.

We argue that the combined conceptual and strategic elements brought forward help to successfully advance adaptive monitoring and ICM implementation in the Dutch Wadden Sea Region. The network and portal are novel in their design because they aim to combine and integrate data on ecological and socioeconomic data, linking research-driven and policy-driven monitoring for comprehensive system analysis that uses indicators of responses, pressures, state, and benefits. We argue this integrated approach is necessary for effectively addressing the major issues facing the region now and in the future.

Like the Great Barrier Reef in Australia, the Wadden Sea has international recognition and is of worldwide importance, as formalized in its World Heritage status. The implementation of a successful monitoring network is essential to support good governance and sustainable management. The WaLTER project may serve as an example to coastal regions in which ecological, economic, and social objectives need to be closely monitored. We believe the overall approach and ideas presented are transferable to other types of complex social-ecological systems to accomplish integrated management processes.

Responses to this article can be read online at: http://www.ecologyandsociety.org/issues/responses. $\mathrm{php} / 7228$

\section{Acknowledgments:}

We thank our colleagues of the WaLTER team for the fruitful discussions on the strategic and conceptual framework of WaLTER. We express our gratitude to Dr. Alma de Groot (IMARES) and Julia Vroom, Msc (Deltares) of the Deltaprogramme Wadden Area for sharpening our ideas on adaptive monitoring and to Dr. Katja Philippart (NIOZ) for critical reading of the manuscript. We express our gratitude to our anonymous reviewers for valuable suggestions enabling significant improvement of the manuscript. This publication is part of the activities performed within the framework of the Wadden Sea Long-Term Ecosystem Research (WaLTER) project, which is funded by the Dutch Waddenfonds and by the Provinces of Noord-Holland and Friesland.

\section{LITERATURE CITED}

Algemene Rekenkamer. 2013. Waddengebied: natuurbescherming, natuurbeheer en ruimtelijke inrichting. (In Dutch) Algemene Rekenkamer, Den Haag, The Netherlands. [online] URL: http:// www.rekenkamer.nl/Publicaties/Onderzoeksrapporten/

Introducties/2013/11/Waddengebied_natuurbescherming_natuurbeheer en ruimtelijke inrichting

Allen, C. R., and L. H. Gunderson. 2011. Pathology and failure in the design and implementation of adaptive management. Journal of Environmental Management 92:1379-1384. http://dx. doi.org/10.1016/j.jenvman.2010.10.063

Armitage, D. R., R. Plummer, F. Berkes, R. I. Arthur, A. T. Charles, I. J. Davidson-Hunt, A. P. Diduck, N. C. Doubleday, D. S. Johnson, M. Marschke, P. McConney, E. W. Pinkerton, and E. K. Wollenberg. 2009. Adaptive co-management for socialecological complexity. Frontiers in Ecology and the Environment 7:95-102. http://dx.doi.org/10.1890/070089

Atkins, J. P., D. Burdon, M. Elliott, and A. J. Gregory. 2011. Management of the marine environment: integrating ecosystem services and societal benefits with the DPSIR framework in a systems approach. Marine Pollution Bulletin 62:215-226. http:// dx.doi.org/10.1016/j.marpolbul.2010.12.012

Belfiore, S., J. Barbière, R. Bowen, B. Cicin-Sain, C. Ehler, C. Mageau, D. McDougall, and R. Siron. 2006. A handbook for measuring the progress and outcomes of integrated coastal and ocean management. UNESCO, Paris, France.

Biggs, R., M. Schlüter, D. Biggs, E. L. Bohensky, S. BurnSilver, G. Cundill, V. Dakos, T. M. Daw, L. S. Evans, K. Kotschy, A. M. Leitch, C. Meek, A. Quinlan, C. Raudsepp-Hearne, M. D. Robards, M. L. Schoon, L. Schultz, and P. C. West. 2012. Toward principles for enhancing the resilience of ecosystem services. Annual Review of Environment and Resources 37:421-448. http:// dx.doi.org/10.1146/annurev-environ-051211-123836

Black, S., and J. Groombridge. 2010. Use of a business excellence model to improve conservation programs. Conservation Biology 24:1448-1458. http://dx.doi.org/10.1111/j.1523-1739.2010.01562. $\underline{\mathrm{X}}$

Bossel, H. 2001. Assessing viability and sustainability: a systemsbased approach for deriving comprehensive indicator sets. Ecology and Society 5(2): 12. [online] URL: http://www.consecol. org/vol5/iss $2 / \operatorname{art} 12 /$

Bowen, R. E., and C. Riley. 2003. Socio-economic indicators and integrated coastal management. Ocean and Coastal Management 46:299-312. http://dx.doi.org/10.1016/S0964-5691(03)00008-5

Cash, D. W., W. C. Clark, F. Alcock, N. M. Dickson, N. Eckley, D. H. Guston, J. Jäger, and R. B. Mitchell. 2003. Knowledge systems for sustainable development. Proceedings of the National Academy of Sciences 100:8086-8091. http://dx.doi.org/10.1073/ pnas. 1231332100

Chapman, P. M. 2012. Adaptive monitoring based on ecosystem services. Science of the Total Environment 415:56-60. http://dx. doi.org/10.1016/j.scitotenv.2011.03.036

Common Wadden Sea Secretariat (CWSS). 2008. Nomination of the Dutch-German Wadden Sea as a World Heritage Site. World 
Heritage Nomination Project Group, Wilhelmshaven, Germany. [online] URL: http://www.waddensea-secretariat.org/management/ whs/whs.html

Conrad, C. C., and K. G. Hilchey. 2011. A review of citizen science and community-based environmental monitoring: issues and opportunities. Environmental Monitoring and Assessment 176:273-291. http://dx.doi.org/10.1007/s10661-010-1582-5

Conservation Measures Partnership (CMP). 2007. Open standards for the practice of conservation. Version 2.0. Conservation Measures Partnership, Washington, D.C., USA. [online] URL: http://cmp-openstandards.org/

Cundill, G., and C. Fabricius. 2009. Monitoring in adaptive comanagement: toward a learning based approach. Journal of Environmental Management 90:3205-3211. http://dx.doi.org/10.1016/ j.jenvman.2009.05.012

Daams, M. N., and F. J. Sijtsma. 2013. Planting the SEED: towards a spatial economic ecological database for a shared understanding of the Dutch Wadden area. Journal of Sea Research 82:153-164. http://dx.doi.org/10.1016/j.seares.2012.12.002

Day, J. 2008. The need and practice of monitoring, evaluating and adapting marine planning and management - lessons from the Great Barrier Reef. Marine Policy 32:823-831. http://dx.doi. org/10.1016/j.marpol.2008.03.023

Douvere, F., and C. N. Ehler. 2011. The importance of monitoring and evaluation in adaptive maritime spatial planning. Journal of Coastal Conservation 15:305-311. http://dx.doi.org/10.1007/ s11852-010-0100-9

European Centre for Business Excellence (ECBE). 1999. The X factor: winning performance through business excellence. British Quality Foundation, Leeds, UK.

European Commission. 2002. Recommendation of the European Parliament and of the Council of 30 May 2002 concerning the implementation of integrated coastal zone management in Europe. European Commission, Brussels, Belgium. [online] URL: http://eur-lex.europa.eu/legal-content/EN/TXT/HTML/? uri=CELEX: $32002 \mathrm{H} 0413 \&$ from $=\mathrm{EN}$

Folke, C., T. Hahn, P. Olsson, and J. Norberg. 2005. Adaptive governance of social-ecological systems. Annual Review of Environment and Resources 30:441-473. http://dx.doi.org/10.1146/ annurev.energy.30.050504.144511

Gudmundsson, H. 2003. The policy use of environmental indicators-learning from evaluation research. Journal of Transdisciplinary Environmental Studies 2(2):1-12. [online] URL: http://www.journal-tes.dk/vol\%202\%20no\%202/Henrik_Gudnundsson_lav. pdf

Hanssen, L., E. Rouwette, and M. M. van Katwijk. 2009. The role of ecological science in environmental policy making: from a pacification toward a facilitation strategy. Ecology and Society 14(1): 43. [online] URL: http://www.ecologyandsociety.org/ vol14/iss $1 / \operatorname{art} 43 /$

Heink, U., and I. Kowarik. 2010. What are indicators? On the definition of indicators in ecology and environmental planning. Ecological Indicators 10:584-593. http://dx.doi.org/10.1016/j. ecolind.2009.09.009
Hockings, M., R. James, S. Stolton, N. Dudley, V. Mathur, J. Makombo, J. Courrau, and J. Parrish. 2008. Enhancing our heritage toolkit. Assessing management effectiveness of natural World Heritage sites. UNESCO World Heritage Centre, Paris, France. [online] URL: http://whc.unesco.org/en/series/23/

Jacobson, C., R. W. Carter, D. C. Thomsen, and T. F. Smith. 2014. Monitoring and evaluation for adaptive coastal management. Ocean and Coastal Management 89:51-57. http://dx.doi. org/10.1016/j.ocecoaman.2013.12.008

Jones, J. P. G., G. P. Asner, S. H. M. Butchart, and K. U. Karanth. 2013. The 'why', 'what' and 'how' of monitoring for conservation. Pages 327-343 in D. W. Macdonald and K. J. Willis, editors. Key topics in conservation Bbiology 2. Wiley-Blackwell, New York, New York, USA. http://dx.doi.org/10.1002/9781118520178.ch18

Kabat, P., J. Bazelmans, J. van Dijk, P. M. J. Herman, T. van Oijen, M. Pejrup, K. Reise, H. Speelman, and W. J. Wolff. 2012. The Wadden Sea region: towards a science for sustainable development. Ocean and Coastal Management 68:4-17. http://dx. doi.org/10.1016/j.ocecoaman.2012.05.022

Kates, R. W., W. C. Clark, R. Corell, J. M. Hall, C. C. Jaeger, I. Lowe, J. J. McCarthy, H. J. Schellnhuber, B. Bolin, N. M. Dickson, S. Faucheux, G. C. Gallopin, A. Grübler, B. Huntley, J. Jäger, N. S. Jodha, R. E. Kasperson, A. Mabogunje, P. Matson, H. Mooney, B. Moore, III, T. O'Riordan, and U. Svedlin. 2001. Sustainability science. Science 292:641-642. http://dx.doi.org/10.1126/science.1059386

Kelble, C. R., D. K. Loomis, S. Lovelace, W. K. Nuttle, P. B. Ortner, P. Fletcher, G. S. Cook, J. J. Lorenz, and J. N. Boyer. 2013. The EBM-DPSER conceptual model: integrating ecosystem services into the DPSIR framework. PLoS ONE 8:e70766. http:// dx.doi.org/10.1371/journal.pone.0070766

Khosravi, A., and M. Chavan. 2012. A comprehensive view on research excellence. Total Quality Management and Business Excellence 23:507-521. http://dx.doi.org/10.1080/14783363.2012.669537

Lindenmayer, D. B., P. Gibbons, M. Bourke, M. Burgman, C. R. Dickman, S. Ferrier, J. Fitzsimons, D. Freudenberger, S. T. Garnett, C. Groves, R. J. Hobbs, R. T. Kingsford, C. Krebs, S. Legge, A. J. Lowe, R. McLean, J. Montambault, H. Possingham, J. Radford, D. Robinson, L. Smallbone, D. Thomas, T. Varcoe, M. Vardon, G. Wardle, J. Woinarski, and A. Zerger. 2012. Improving biodiversity monitoring. Austral Ecology 37:285-294. http://dx.doi.org/10.1111/j.1442-9993.2011.02314.x

Lindenmayer, D. B., and G. E. Likens. 2009. Adaptive monitoring: a new paradigm for long-term research and monitoring. Trends in Ecology and Evolution 24:482-486.

Lindenmayer, D. B., and G. E. Likens. 2010. The science and application of ecological monitoring. Biological Conservation 143:1317-1328. http://dx.doi.org/10.1016/j.biocon.2010.02.013

Liu, J., T. Dietz, S. R. Carpenter, M. Alberti, C. Folke, E. Moran, A. N. Pell, P. Deadman, T. Kratz, J. Lubchenco, E. Ostrom, Z. Ouyang, W. Provencher, C. L. Redman, S. H. Schneider, and W. W. Taylor. 2007. Complexity of coupled human and natural systems. Science 317:1513-1516. http://dx.doi.org/10.1126/ science. 1144004 
Maxim, L., J. H. Spangenberg, and M. O'Connor. 2009. An analysis of risks for biodiversity under the DPSIR framework. Ecological Economics 69:12-23. http://dx.doi.org/10.1016/j. ecolecon.2009.03.017

McFadden, J. E., T. L. Hiller, and A. J. Tyre. 2011. Evaluating the efficacy of adaptive management approaches: is there a formula for success? Journal of Environmental Management 92:1354-1359. http://dx.doi.org/10.1016/j.jenvman.2010.10.038

Olsen, S. B., and D. Nickerson. 2003. The governance of coastal ecosystems at the regional scale: an analysis of the strategies and outcomes of long-Term Programs. Coastal Management Report \#2243, University of Rhode Island Coastal Resources Center, Narragansett, RI.

Parr, T. W., A. R. J. Sier, R. W. Battarbee, A. Mackay, and J. Burgess. 2003. Detecting environmental change: science and society--perspectives on long-term research and monitoring in the 21 st century. Science of the Total Environment 310:1-8. http://dx. doi.org/10.1016/S0048-9697(03)00257-2

Pomeroy, R. S., L. M. Watson, J. E. Parks, and G. A. Cid. 2005. How is your MPA doing? A methodology for evaluating the management effectiveness of marine protected areas. Ocean and Coastal Management 48:485-502. http://dx.doi.org/10.1016/j. ocecoaman.2005.05.004

Pullin, A. S., and G. B. Stewart. 2006. Guidelines for systematic review in conservation and environmental management. Conservation Biology 20:1647-1656. http://dx.doi.org/10.1111/ j.1523-1739.2006.00485.x

Rapport, D. J., and M. Hildén. 2013. An evolving role for ecological indicators: from documenting ecological conditions to monitoring drivers and policy responses. Ecological Indicators 28:10-15. http://dx.doi.org/10.1016/j.ecolind.2012.05.015

Regiecollege Waddengebied (RCW). 2014. Plan van aanpak verbetering beheer Waddenzee. "Samenwerkingsagenda beheer Waddenzee". (In Dutch). Regiecollege Waddengebied/Beheerraad Waddengebied, Leeuwarden, The Netherlands. [online] URL: http://www.rijksoverheid.nl/documenten-en-publicaties/ rapporten/2014/07/02/plan-van-aanpak-verbetering-beheer-waddenzeesamenwerkingsagenda-beheer-waddenzee.html

Reed, M. S., A. C. Evely, G. Cundill, I. Fazey, J. Glass, A. Laing, J. Newig, B. Parrish, C. Prell, C. Raymond, and L. C. Stringer. 2010. What is social learning? Ecology and Society 15(4): r1. [online] URL: http://www.ecologyandsociety.org/vol15/iss4/ resp1/

Rist, L., A. Felton, L. Samuelsson, C. Sandström, and O. Rosvall. 2013. A new paradigm for adaptive management. Ecology and Society 18(4): 63. http://dx.doi.org/10.5751/ES-06183-180463

Runhaar, H., and K. van Nieuwaal. 2010. Understanding the use of science in decision-making on cockle fisheries and gas mining in the Dutch Wadden Sea: putting the science-policy interface in a wider perspective. Environmental Science and Policy 13:239-248. http://dx.doi.org/10.1016/j.envsci.2010.03.001

Sherman, K. 2014. Adaptive management institutions at the regional level: the case of large marine ecosystems. Ocean and Coastal Management 90:38-49. http://dx.doi.org/10.1016/j. ocecoaman.2013.06.008
Sijtsma, F. J., M. N. Daams, H. Farjon, and A. E. Buijs. 2012. Deep feelings around a shallow coast. A spatial analysis of tourism jobs and the attractivity of nature in the Dutch Wadden area. Ocean and Coastal Management 68:138-148. http://dx.doi. org/10.1016/j.ocecoaman.2012.05.018

Sparks, T. H., S. H. M. Butchart, A. Balmford, L. Bennun, D. Stanwell-Smith, M. Walpole, N. R. Bates, B. Bomhard, G. M. Buchanan, A. M. Chenery, B. Collen, J. Csirke, R. J. Diaz, N. K. Dulvy, C. Fitzgerald, V. Kapos, P. Mayaux, M. Tierney, M. Waycott, L. Wood, and R. E. Green. 2011. Linked indicator sets for addressing biodiversity loss. Oryx 45:411-419. http://dx.doi. org/10.1017/S003060531100024X

Stojanovic, T., R. C. Ballinger, and C. S. Lalwani. 2004. Successful integrated coastal management: measuring it with research and contributing to wise practice. Ocean and Coastal Management 47:273-298. http://dx.doi.org/10.1016/j.ocecoaman.2004.08.001

Taljaard, S., J. H. Slinger, and J. H. van Der Merwe. 2011. Criteria for evaluating the design of implementation models for integrated coastal management. Coastal Management 39:628-655. http://dx. doi.org/10.1080/08920753.2011.616670

Taljaard, S., J. H. Slinger, and J. van der Merwe. 2013. Dual adaptive cycles in implementing integrated coastal management. Ocean and Coastal Management 84:23-30. http://dx.doi. org/10.1016/j.ocecoaman.2013.07.003

Timmerman, J. G., J. J. Ottens, and R. C. Ward. 2000. The information cycle as a framework for defining information goals for water-quality monitoring. Environmental Management 25:229-239. http://dx.doi.org/10.1007/s002679910018

Turnhout, E., M. Hisschemöller, and H. Eijsackers. 2007. Ecological indicators: between the two fires of science and policy. Ecological Indicators 7:215-228. http://dx.doi.org/10.1016/j. ecolind.2005.12.003

Vugteveen, P. 2013. Connecting the dots. A critical analysis of a tangled concept. Dissertation. Radboud University, Nijmegen, The Netherlands. [online] URL: http://repository.ubn.ru.nl/ handle/2066/107671

Vugteveen, P., E. Rouwette, H. Stouten, and L. Hanssen. $2014 b$. Group model building over mosselvisserij in de Waddenzee. WaLTER project. Radboud University, Nijmegen, The Netherlands. (In Dutch). [online] URL: http://www.walterwaddenmonitor. org/publicaties/

Vugteveen, P., E. Rouwette, H. Stouten, M. M. van Katwijk, and L. Hanssen. 2014c. Group model building over toerisme in het Waddengebied. WaLTER project. Radboud University, Nijmegen, The Netherlands. (In Dutch). [online] URL: http:// www.walterwaddenmonitor.org/publicaties/

Vugteveen, P., M. M. van Katwijk, E. Rouwette, and L. Hanssen. $2014 a$. How to structure and prioritize information needs in support of monitoring design for integrated coastal management. Journal of Sea Research 86:23-33. http://dx.doi.org/10.1016/j. seares.2013.10.013

Waddenfonds. 2014. Ontwerp uitvoeringsplan Waddenfonds 2014-2017. (In Dutch). Waddenfonds, Leeuwarden, The Netherlands. [online] URL: http://www.provinciegroningen.nl/ fileadmin/user upload/Documenten/Downloads/Ontwerp-

Uitvoeringsplan 2014-2017.pdf 
WaLTER project team. 2010. WaLTER - Wadden Sea long-term ecosystem research. Projectplan Waddenfondsaanvraag Tender 2010/1. NIOZ, Den Burg, The Neterlands. (In Dutch). [online] URL: http://www.waddenacademie.nl/fileadmin/inhoud/ pdf/02 taken/2010 04 28u WaLTER Projectplan.pdf

Williams, B. K., and E. D. Brown. 2014. Adaptive management: from more talk to real action. Environmental Management 53:465-479. http://dx.doi.org/10.1007/s00267-013-0205-7 